\title{
DEVELOPMENT OF SPEED MANIFESTATION FORMS DURING PHYSICAL EDUCATION CLASSES AT UNIVERSITY
}

\author{
L.G. Talaghir ${ }^{1}$, gtalaghir@ugal.ro, ORCID: 0000-0002-3133-9192, \\ G.D. Mocanu', gmocanu@ugal.ro, ORCID: 0000-0002-4763-4700, \\ T.M. Iconomescu', ticonomescu@ugal.ro, ORCID: 0000-0001-5780-4403, \\ V. Mîndrescu', veronica_mindrescu@yahoo.com, ORCID: 0000-0003-0382-6206 \\ ${ }^{1}$ "Dunarea de Jos" University of Galati, Galati, Romania, \\ ${ }^{2}$ Transilvania University of Braşov, Braşov, Romania
}

\begin{abstract}
Aim. The aim of our research was to elaborate and assess the method for the development of speed as a motor skill applied in the experimental study with the mention that all the methods can be reunited in the form of the repetition method with four related procedures. Materials and methods. The experimental study took place during the academic year 2016/2017 and was carried out in groups of students-volunteers from faculties within Lower Danube University of Galaţi. The study implied 56 hours for the development and assessment of speed as a motor skill. Results. The tests used allowed us to assess all the important forms of speed manifestation and their combinations with other motor skills. The obtained results and statistical calculations demonstrated viability and effectiveness of our experimental curriculum. The correlative analysis highlighted the connections that exist between the different forms of speed manifestation, but also the differences that occur depending on sex and other characteristics of each analyzed group. Conclusion. The results obtained allow us to assess objectively the level of speed manifestation in students, but they are also a wake-up call regarding students' deficiency in physical training and anaerobic effort capacity, specific to the intense actions that characterize the development and manifestation of this skill, which is extremely difficult to improve.
\end{abstract}

Keywords: PE classes at university, reaction time and repetition speed, motor skills, acceleration capacity, intense effort.

Introduction. The training of speed-strength and speed-endurance combinations are exploited, due to the better tolerance to intense effort and to effort that implies endurance, the body better adapts to them, by improving the alactacid and lactacid anaerobic energy mechanisms $[4,5,8$, 10]. Investigation in the lifestyle of the younger generation has, in recent years, highlighted a drastic reduction in physical activity habits and sedentary lifestyle $[1,9,15]$.

The aim of the study is to analyse the index value of speed as a motor skill for this age category and the progress that can be made by taking into account the fact that speed depends on hereditary factors. Most of sport branches that involve speed are very harsh in the selection process due to the reduced chance of recording spectacular progress as compared to endurance, flexibility or muscle strength values $[10,11]$. However, significant progress may also be recorded in low-trained groups, as opposed to high-performance athletes, who have already reached the upper speed limit. The improvement of speed indices is difficult and often correlates with progress in the accumula- tion of strength and superior coordination of movements / technique improvement [3, 12, 18].

The importance of speed in the manifestation of motor skills is obvious in rapid reflex movements, in every day sensory stresses or in sports activities such as explosive jumping, throwing, kicking, balancing etc. [6, 8, 13, 14].

However, speed often implies high, submaximal and maximal loads. Movements performed with less than $85 \%$ of maximum individual speed do not result in improvements in this area due to the fact that fast speed units / white fast twitch fibres, innervated by large $\alpha$-motor neurons that provide explosive movements, are not used [16, 17, 19, 20].

The methods of speed development - as they are described in the domain-specific literature, which we applied in the experimental study are systematized in Figure 1, with the mention that all the methods can be reunited in the form of the repetition method, with the four related procedures. Their use was performed selectively or combined in the proposed training program, with age-appropriate exercises, which were as 


\section{Спортивная тренировка}

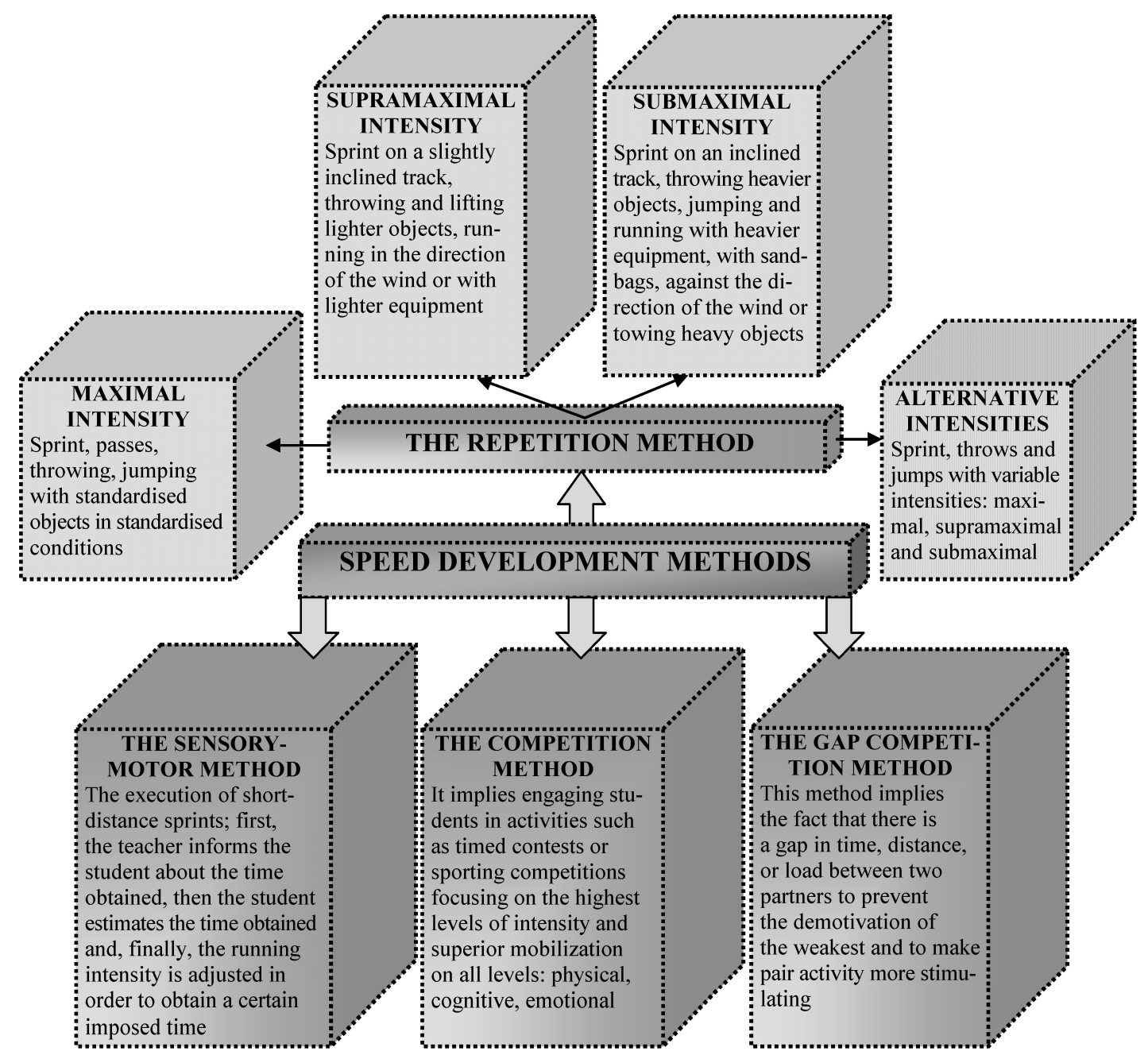

Fig. 1. Methodology used in the experimental curriculum for speed development

attractive as possible, in order to facilitate greater effort engagement $[2,15,20]$.

\section{Materials and methods}

Subjects. Students-volunteers of the abovementioned faculties, the group of 240 boys and the group of 104 girls, participated in the study. We took into account only those students who were not absent during the activities and who were actively involved in all the lessons in which speed as a motor ability was influenced. The average age of boys is 22.8 years, the average age of girls -22.5 years.

The implementation of the experimental curriculum was done only after the students were presented with the purpose and duration of the research, the working methodology and the assessment tests used, and the management of the higher education institution agreed with this approach and the use of the equipment.

Procedure. The experimental study was conducted during physical education classes in the following faculties: Automation, Computer Science, Electrical and Electronic Engineering, Law, Food Science and Engineering, Economics and Business Administration. All participants belonged to the first and second years of study. The implementation of the curriculum aimed at speed improvement was achieved during two semesters of the academic year 2016/2017, cumulating 28 weeks and 56 hours of physical education and a period that included both the initial and final tests.

Methods. The assessment tests made it possible to verify the development of several speed manifestation forms and combinations with other abilities: speed of reaction, execution, repetition, acceleration and deceleration, uniform and nonuniform speed, movement speed, speed combined with strength, coordination and endurance. The main tests used are: tapping test, falling baton test, Edgren speed test, 20-m agility test, Adams speed test, $50-\mathrm{m}$ sprint test, visual response to 
visual stimuli test, speed test, acceleration test $(30 \mathrm{~m}+30 \mathrm{~m})$, determination of the maximum running speed, 9-3-6-3-9 test, great marathon test. Tests were performed on dependent samples between the initial measurement and the final measurement for each. The data obtained were analysed with the Paired Student Test and Pearson Correlations. All analyses were performed using SPSS version 23.0.

Results. The analysis and interpretation of the results of statistical calculation is presented in tables 1 and 2 below.

Most girls initially obtained high values at right tapping test, as compared to the results obtained for left tapping test.

Results highlight a higher frequency of movements for the right hand - predominantly used in different activities - for both sexes. Interestingly, the differences between the initial and final testing environments are not significant for girls but statistically significant for boys.
For falling baton test, girls recorded lower final average values than the initial ones. The group of boys recorded small progress between the initial and final tests. It should be noticed that this is the only test in which the boys in the experimental group did not show significant progress.

Girls and boys demonstrated enhanced performance in Edgren test. It is worth mentioning that all students preferred the variant of side jumps on consecutive lines - which bring only one point for each successful jump - avoiding long lateral jumps, which were hard to tackle which would have allowed 2 points for each successful jump.

In agility test, significant progress is registered for both sexes, which was statistically significant.

Adams test is marked by improved results for both genders, but also by a considerable reduction in the final test of cases in which the number

Significance of the difference between the averages per pair samples

Table 1

\begin{tabular}{|c|c|c|c|c|c|c|c|c|}
\hline \multirow[b]{3}{*}{ Tests } & \multicolumn{8}{|c|}{$\begin{array}{c}\text { Pair samples } \\
\text { Non-specialised groups }\end{array}$} \\
\hline & \multicolumn{4}{|c|}{ Girls $(\mathrm{N}=106)$} & \multicolumn{4}{|c|}{ Girls $(\mathrm{N}=106)$} \\
\hline & $\begin{array}{c}\text { I.T. } \\
\bar{x} \pm \mathrm{m}\end{array}$ & $\begin{array}{c}\text { F.T. } \\
\overline{\mathrm{x}} \pm \mathrm{m}\end{array}$ & $\mathrm{t}$ & $\begin{array}{l}\text { P Sig. } \\
\text { 2-tailed }\end{array}$ & $\begin{array}{c}\text { I.T. } \\
\bar{x} \pm \mathrm{m}\end{array}$ & $\begin{array}{c}\text { F.T. } \\
\overline{\mathrm{x}} \pm \mathrm{m}\end{array}$ & $\mathrm{t}$ & $\begin{array}{l}\text { P Sig. } \\
\text { 2-tailed }\end{array}$ \\
\hline Tapping test right / dots & $45.73 \pm .72$ & $45.68 \pm .72$ & .54 & .590 & $48.12 \pm .51$ & $48.55 \pm .48$ & -3.33 & $.001^{*}$ \\
\hline Tapping test left / dots & $39.82 \pm .61$ & $39.83 \pm .59$ & -.14 & .887 & $42.70 \pm .49$ & $42.98 \pm .45$ & -2.03 & $.043^{*}$ \\
\hline Falling baton $/ \mathrm{cm}$ & $28.71 \pm .698$ & $28.80 \pm .67$ & -.69 & .487 & $25.02 \pm .49$ & $24.78 \pm .45$ & 1.57 & .116 \\
\hline Edgren test / points & $10.45 \pm .24$ & $10.88 \pm .24$ & -4.82 & $.000^{* *}$ & $13.92 \pm .15$ & $14.41 \pm .13$ & -8.31 & $.000^{* *}$ \\
\hline Agility test / sec & $6.79 \pm .05$ & $6.69 \pm .05$ & 12.35 & $.000^{* *}$ & $5.83 \pm .03$ & $5.78 \pm .02$ & 14.36 & $.000^{* *}$ \\
\hline $\begin{array}{l}\text { Adams test correct / } \\
\text { no. of jumps }\end{array}$ & $16.45 \pm .48$ & $17.05 \pm .45$ & -5.35 & $.000^{* *}$ & $18.07 \pm .36$ & $18.68 \pm .31$ & -6.08 & $.000^{* *}$ \\
\hline $\begin{array}{l}\text { Adams test incorrect / } \\
\text { no. of jumps }\end{array}$ & $4.65 \pm .34$ & $3.84 \pm .32$ & 5.99 & $.000^{* *}$ & $6.16 \pm .23$ & $4.80 \pm .19$ & 13.94 & $.000^{* *}$ \\
\hline 50-m sprint test /sec & $9.63 \pm .09$ & $9.54 \pm .09$ & 12.23 & $.000^{* *}$ & $7.43 \pm .03$ & $7.36 \pm .03$ & 12.67 & $.000^{* *}$ \\
\hline $\begin{array}{l}\text { Visual response } \\
\text { to visual stimuli test / } \\
\text { sec }\end{array}$ & $0.36 \pm .00$ & $0.36 \pm .00$ & -.50 & .618 & $0.32 \pm .00$ & $0.33 \pm .00$ & -2.09 & $.037^{*}$ \\
\hline Speed test / sec & $21.61 \pm .18$ & $21.43 \pm .19$ & 14.66 & $.000^{* *}$ & $18.06 \pm .10$ & $17.94 \pm .10$ & 25.16 & $.000^{* *}$ \\
\hline $\begin{array}{l}0-30 \mathrm{~m} / \mathrm{sec} \\
\text { acceleration test }\end{array}$ & $5.81 \pm .04$ & $5.76 \pm .04$ & 13.15 & $.000^{* *}$ & $4.67 \pm .20$ & $4.62 \pm .20$ & 16.91 & $.000^{* *}$ \\
\hline $\begin{array}{l}30-60 \mathrm{~m} / \mathrm{sec} \text { running } \\
\text { test }\end{array}$ & $5.46 \pm .05$ & $5.42 \pm .05$ & 15.53 & $.000^{* *}$ & $4.11 \pm .20$ & $4.07 \pm .02$ & 23.45 & $.000^{* *}$ \\
\hline $\begin{array}{l}\text { Difference } \\
\text { in acceleration test / sec }\end{array}$ & $0.34 \pm .03$ & $0.34 \pm .03$ & .51 & .605 & $0.55 \pm .01$ & $0.54 \pm .01$ & 4.71 & $.000^{* *}$ \\
\hline $\begin{array}{l}\text { Maximum running } \\
\text { speed / } \mathrm{m} / \mathrm{sec}\end{array}$ & $5.54 \pm .05$ & $5.58 \pm .05$ & -14.92 & $.000^{* *}$ & $7.34 \pm .04$ & $7.41 \pm .04$ & -22.55 & $.000^{* * *}$ \\
\hline $9-3-6-3-9$ test / sec & $10.85 \pm .08$ & $10.79 \pm .08$ & 12.05 & $.000^{* *}$ & $9.45 \pm .05$ & $9.40 \pm .05$ & 13.38 & $.000^{* *}$ \\
\hline $\begin{array}{l}\text { Great marathon test / } \\
\text { sec }\end{array}$ & $27.16 \pm .18$ & $26.97 \pm .18$ & 11.96 & $.000^{* *}$ & $23.07 \pm .10$ & $22.89 \pm .09$ & 23.81 & $.000^{* *}$ \\
\hline
\end{tabular}

Note. $* \mathrm{P}<0.01, * * \mathrm{P}<0.001$. 


\section{Спортивная тренировка}

of incorrect jumps is higher than the correct ones. For the rest of the students there is a higher number of correct jumps. In the final tests, there is a decrease in the cases in which the number of incorrect jumps is higher than the correct ones.

In the final tests the improvement registered in the statistically confirmed results can also be explained by an adjustment of the coordination processes, improvement in the accuracy of the movements and space orientation, as well as in the speed of repetition and jumping reach. Progress in the speed of movement ability is represented by the improved results obtained in $50-\mathrm{m}$ sprint test for both genders.

Assessing the speed of reaction to visual stimuli - by means of existing Internet tests results in a slight decrease in performance, which is explained by the fact that the proposed experimental curriculum is based on other types of physical activities that have nothing to do with the movement which is specific to the test itself. The decrease is, however, less important in girls, which was insignificant. In boys, there is a difference between environments generating stronger regression, which was significant. The results of this test are contradictory and are greatly influenced by the ability to focus on the spot, visual acuity, familiarity with the test etc.

In speed test, both genders recorded a significant improvement in performance. The difference between girls' averages generates a result of $\mathrm{t}=14.666$, corresponding to a limit $\mathrm{P}=0.000$, value $<0.001$, which was highly significant. The difference between the boys' averages generates a result of $\mathrm{t}=25.166$, corresponding to a limit $\mathrm{P}=0.000$, value $<0.001$, which was also highly significant. The differences can be explained by an improvement in acceleration and deceleration, in spatial orientation, in dynamic balance and in the speed of movement under endurance conditions.

30-m accelerated running and 30-60-m running tests both recorded significant progress for girls and boys. The problem arises with the difference between the average times recorded on the two portions, which should have positive values due to the fact that, under normal conditions, the time obtained for $30-60-\mathrm{m}$ is shorter and, therefore, better than for the first $30 \mathrm{~m}$, when the student accelerates in order to reach maximum speed.

There are 16 cases regarding initial tests for the group of girls $-15.09 \%$ of the studied group - and 2 cases regarding the initial tests for the group of boys $-0.83 \%$ of the studied group which obtained negative values concerning the difference between the times of two tests, i.e. poor times on the second portion as compared to the first, where the student accelerates. The problem is not improved in final results, where the situation is maintained for 15 girls and for two boys, fact which demonstrates that progress in speed is difficult to achieve. The explanation would be the inability of the students to maintain the maximum speed reached at the end of the first $30-\mathrm{m}$ acceleration in the second part of effort, that is, 30-60-m running, which shows poor adaptation to effort and poor physical condition. Another aspect highlighted in the tests is that some students were not able to accelerate too much on the first $30-\mathrm{m}$ section, and they continued to accelerate and reached the maximum speed on the second $30-\mathrm{m}$ section, thus the time differences between the two portions are reduced. Another reported problem is that poor running performance affects performance in speed test.

The maximum running speed, determined on $30-60 \mathrm{~m}$ portion - where it is possible to reach the highest speed - has significant increases for both sexes. The fact that they start training from low speed manifestation level can explain this significant progress in speed.

9-3-6-3-9 and great marathon tests also show superior performance for both sexes. We should take into consideration the fact that these two tests mainly require a combination of speed with other motor skills: strength, agility, space orientation, dynamic balance etc.

Interpreting the obtained Pearson correlation coefficients (r), according to Table 2, it should be taken into account that a series of tests are atypical, i.e. the low value of results actually indicates that performance increased and vice versa.

Conclusions. The experimental study conducted allowed us to perform an objective assessment of the development of different forms of speed manifestation, for a particular social category, the students being mostly sedentary or rarely involved in independent physical activities. This negative aspect is generated by lifestyle, work habits, the prevailing intellectual demands of their specializations, and the lack of awareness of the negative effects of lack of movement on their health status and long-term exercise capacity. 


\begin{tabular}{|c|c|c|c|c|c|c|c|c|c|c|c|c|c|c|c|c|}
\hline 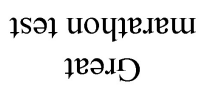 & $\overbrace{}^{n}$ & $\stackrel{2}{\infty}$ & 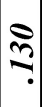 & 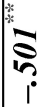 & $\mid$ & $\hat{N}$ & $\stackrel{n}{a}$ & $\stackrel{N}{N}$ & $\stackrel{1}{*}$ & : & $\stackrel{\infty}{n}$ & $\stackrel{*}{*}$ & $\stackrel{n}{1}$ & है & $\stackrel{0}{\infty}$ & - \\
\hline $\begin{array}{c}\text { 7Sว। } \\
6-\varepsilon-9-\varepsilon-6\end{array}$ & ? & $\frac{7}{1}$ & $\stackrel{+}{8}$ & 8 & (ָ) & 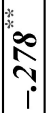 & $\stackrel{8}{\circ}$ & "? & $\ddot{\infty}$ & $\hat{\hat{n}}$ & $\frac{*}{6}$ & ? & $\stackrel{\infty}{\sigma}$ & $\frac{2}{5}$ & - & $\stackrel{*}{\circ}$ \\
\hline $\begin{array}{c}\text { pəəds } \\
\text { ôu!̣un. } \cdot \text { xeW }\end{array}$ & $\stackrel{n}{\tau}$ & $\hat{\imath}$ & $\stackrel{3}{7}$ & 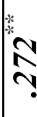 & $\begin{array}{lll}m \\
n \\
n \\
n \\
n\end{array}$ & ?. & $\stackrel{n}{\frac{1}{1}}$ & 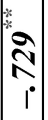 & $\stackrel{\infty}{\circ}$ & مै & $\stackrel{8}{i}$ & $\stackrel{8}{10}$ & ? & - & 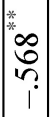 & $\stackrel{*}{6}$ \\
\hline 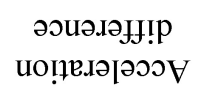 & $\frac{8}{1}$ & $\hat{\widehat{a}}$ & $\hat{\sigma}_{0}^{0}$ & 8 & $\left|\begin{array}{c}\infty \\
\infty \\
1 \\
1\end{array}\right|$ & $\stackrel{2}{-2}$ & $\stackrel{\overbrace{}}{\Im}$ & $\underset{1}{ \pm}$ & 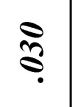 & 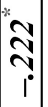 & $\cong$ & 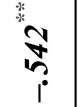 & - & 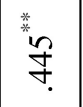 & 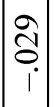 & $\stackrel{m}{o}$ \\
\hline 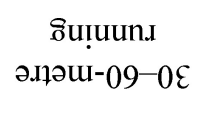 & $\frac{8}{1}$ & $\stackrel{\infty}{i}$ & 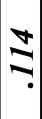 & ֻ & $\check{2}$ & 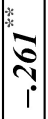 & $\tilde{ล}$ & กิ & $\hat{\hat{\theta}}$ & ลิ & $\stackrel{\infty}{?}$ & - & i. & $\begin{array}{l}\infty \\
\infty \\
\infty\end{array}$ & * & 㐘 \\
\hline 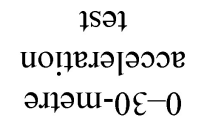 & 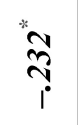 & $\frac{\pi}{1}$ & : & $\stackrel{8}{2}$ & ?ִ & $\frac{2}{2}$ & $\stackrel{\star}{\longleftarrow}$ & 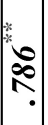 & $\stackrel{\infty}{=}$ & - & - & 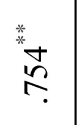 & ণ & "in & \%ั. & 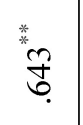 \\
\hline ISəI pəədS & m. & $\stackrel{*}{\stackrel{*}{*}}$ & $\stackrel{\infty}{-}$ & ? & 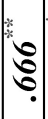 & $\frac{2}{\tau}$ & $\stackrel{\infty}{\infty}$ & 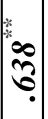 & "? & - & 荽 & $\frac{\text { * }}{\text { * }}$ & $\frac{0}{0}$ & 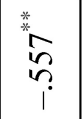 & 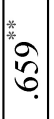 & $\begin{array}{l}\text { *. } \\
12 \\
\infty \\
0\end{array}$ \\
\hline 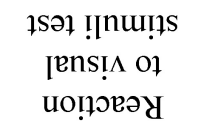 & $\underset{i}{*}$ & $\stackrel{8}{\stackrel{0}{0}}$ & ? & $\overbrace{}^{\circ}$ & $\stackrel{0}{-1}$ & $\left|\begin{array}{c}0 \\
0 \\
0 \\
1\end{array}\right|$ & ลิ. & จุ & - & 象 & 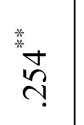 & $\stackrel{\vec{n}}{\stackrel{*}{*}}$ & $\stackrel{\infty}{8}$ & $\stackrel{\frac{*}{3}}{\frac{1}{1}}$ & 蒾 & * \\
\hline qu!̣ds & 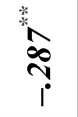 & $\hat{\mathrm{N}}$ & $\underset{7}{\beth}$ & ? & ? & $\frac{2}{\tau}$ & $\frac{1}{8}$ & - & $\stackrel{\text { * }}{\underset{*}{*}}$ & $\begin{array}{l} \\
\infty \\
\infty \\
\infty \\
n \\
n\end{array}$ & 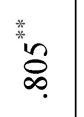 & 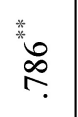 & $\underset{i}{\stackrel{O}{O}}$ & $\stackrel{\text { * }}{\stackrel{9}{\gtrless}}$ & $\bar{*}$ & $\stackrel{*}{*} \frac{1}{7}$ \\
\hline 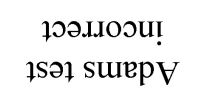 & $\underset{1}{8}$ & $\stackrel{\infty}{\stackrel{\infty}{\circ}}$ & $\overline{\mathrm{s}}$ & $\stackrel{\circ}{\square}$ & $\hat{2}$ & "? & - & $\frac{0}{5}$ & $\hat{o}$ & \begin{tabular}{l}
0 \\
\multirow{2}{0}{} \\
0
\end{tabular} & 호. & ষ & $\hat{\sigma}$ & $\bar{\Xi}_{\dot{I}}$ & $\tilde{n}$ & তু \\
\hline 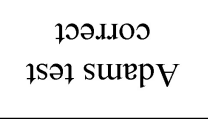 & $\stackrel{*}{*}$ & $\stackrel{*}{\stackrel{*}{r}}$ & $\underset{1}{\varpi}$ & ֶั้ & 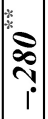 & - & 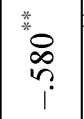 & 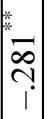 & $\stackrel{m}{=}$ & 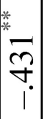 & 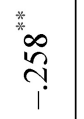 & 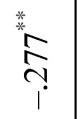 & $\stackrel{\infty}{0}$ & $\begin{array}{l}* \\
6 \\
n \\
n\end{array}$ & 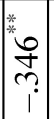 & $\frac{*}{?} \frac{6}{?}$ \\
\hline 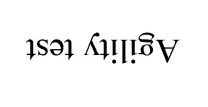 & $\stackrel{*}{*} \underset{i}{*}$ & 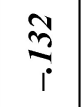 & $\underset{?}{-}$ & $\underset{\nabla}{\nabla}$ & - & 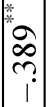 & Oీ & 艾 & 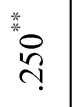 & $\frac{*}{\nabla}$ & $\stackrel{*}{*}$ & $\overline{8}$ & $\tilde{n}^{n}$ & 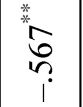 & 产 & $\frac{*}{6}$ \\
\hline 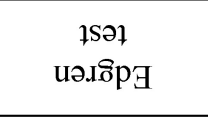 & $\stackrel{n}{a}$ & 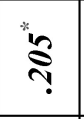 & $\underset{1}{\hat{\theta}}$ & - & $\frac{m}{6}$ & 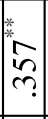 & ஓ & 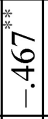 & "ָ & $\bar{n}$ & 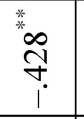 & 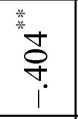 & ষ্ & $\begin{array}{l}\text { * } \\
\text { ? }\end{array}$ & 落 & $\begin{array}{l}* \\
\text { *n } \\
n \\
n\end{array}$ \\
\hline 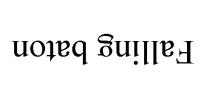 & $\stackrel{8}{\circ}$ & $\stackrel{\infty}{8}$ & - & $\infty$ & $\stackrel{m}{=}$ & 足 & क् & $\stackrel{a}{=}$ & กิ กิ & in & ஃ̊ & क & ᄋे & $\hat{\mathrm{g}}$ & $\stackrel{m}{I}$ & $\underset{i}{\stackrel{N}{~}}$ \\
\hline 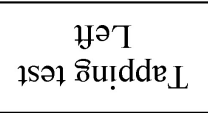 & $\stackrel{*}{*}$ & - & $\frac{m}{n}$ & 으. & $\begin{array}{l}0 \\
\stackrel{0}{0} \\
\stackrel{1}{*}\end{array}$ & 志 & $\sqrt[n]{0}$ & $\begin{array}{c}0 \\
0 \\
0 \\
1 \\
\end{array}$ & 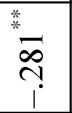 & $\overline{\mathbf{g}}$ & $\frac{ \pm}{0}$ & $\overline{8}$ & $\frac{1}{0}$ & $\frac{N}{0}$ & $\mid \begin{array}{c}1 \\
\infty \\
0 \\
1 \\
1\end{array}$ & 8 \\
\hline 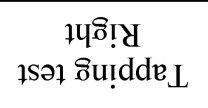 & - & 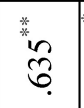 & $\stackrel{6}{6}$ & $\stackrel{2}{0}$ & 今̂. & 8 & ๙ิ & 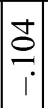 & 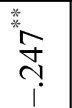 & 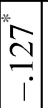 & $\stackrel{3}{\risingdotseq}$ & 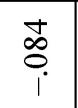 & $\frac{n}{0}$ & 今. & $\begin{array}{c}0 \\
\infty \\
0 \\
1\end{array}$ & $\stackrel{\infty}{5}$ \\
\hline กิ & 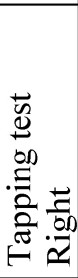 & 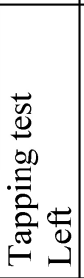 & 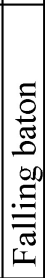 & 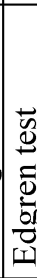 & 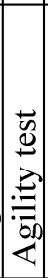 & 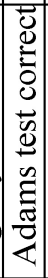 & 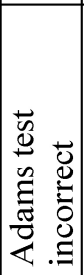 & 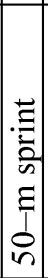 & 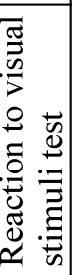 & 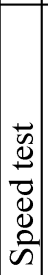 & 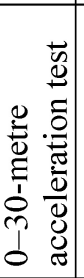 & 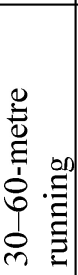 & 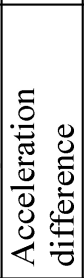 & 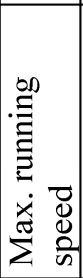 & 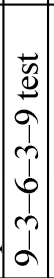 & 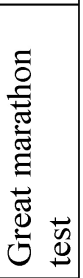 \\
\hline
\end{tabular}




\section{Спортивная тренировка}

The implemented experimental curriculum throughout the entire academic year - demonstrates its effectiveness in most tests, with both groups achieving significant progress, even if the number of hours allocated weekly is very low: a 2-hour module for each study group. Improving performance for both sexes should also take into account the fact that the level of the initial training was very low, and this aspect facilitated the visible improvement of the results. It must be noted that in the case of tests where the motor structures are not known or familiar (right tapping test and left tapping test, falling baton test, reaction to visual stimulus test), the differences are not significant for the group of girls but they are significant for the limit $(\mathrm{P}<0.05)$ in the case of boys.

The tests used cover almost all forms of speed manifestation and its combinations with other abilities: the reaction rate of upper limbs to visual stimuli, the speed of execution and repetition speed, acceleration and deceleration capability, agility, speed in combination with strength, speed in combination with coordination, speed in combination with resistance. The speed form, which wasn't tested separately, is the reaction rate of the lower limbs, but its level of manifestation is a mandatory condition in all tests that involve starting a race at the teacher's signal.

The methods of the experimental curriculum departures and stops using various positions, accelerations and sudden changes in direction, technical structures used in sports games, carried out repeatedly and with a high frequency, movement games having different themes, different types of exercises in the form of contest, various jumps, throws with different objects etc. - were specifically planned for the first part of a weekly physical activity class and no reluctant attitudes from the groups were reported. However, especially in the group of girls and, in isolated cases, in the group of boys, there was a slight maladaptation to the short and intense efforts that characterize the development of speed, which was confirmed by the reduced acceleration capacity and especially visible difficulties in maintaining maximum running speed. This situation is worrying, especially since the students' age should coincide with achieving individual superior results in speed and with a high capacity effort. Many of the tested students do not meet the standard times established for obtaining mark 5 in the $12^{\text {th }}$ grade in high school in 50-m sprint test, i.e. 9 seconds for girls and 8.2 seconds for boys, this being a serious wake-up call regarding the motor skills of the young generation.

The calculation of correlation coefficients highlighted the mutual interdependence and mutual support of the tests used in speed assessment, although distinct features appear for each group, some tests that significantly correlate for the girls are not significantly correlated for the boys and vice versa. The only possible explanation for these inconsistencies is related to the particularities and dynamics of the respective group, since the same tests applied to the students of the Faculty of Physical Education and Sport generated other results regarding the correlation coefficients. It should be noted, however, that where correlations are strong, for values of $r$ within the range $( \pm 0.5-1)$, both genders usually registered significant associations between tests.

It is advisable to continue the investigations and assess students' motor skills, especially through tests that highlight the development of those motor skills that support speed, i.e. muscle / explosive strength assessment in different segments of the body and coordination skills.

The present paper is the result of the equal contribution of all authors.

\section{References}

1. Andréi M.H., Hastie P. [Sport Education in a Higher Education Physical Activity Course]. European Journal of Physical Education and Sport Science, 2017, iss. 3, no. 6, pp. 22-34.

2. Berhanu T.G. [Comparative Study of Physical Fitness Components between Physical and Non-Physical Education Male Students in Nekemte College of Teacher Education]. International Journal of Scientific and Research Publications, 2017, iss. 7, no. 6, pp. 35-43.

3. Bompa T.O. [The Development of Bio Motor Abilities]. București, Ex Ponto Publ., 2001, pp. 213-248.

4. Bota A. [Kinesiology]. Bucuresti, Didactică si Pedagogică Publ., 2007, pp. 318-321.

5. Garcíaa G.C., Secchib J.D., Arcuric C.R., [Relationship Between the Final Speed Reached the UMTT and UNCa Test in Male Subjects]. Apunts. Medicina de l'Esport, 2016, iss. 51, no. 190 , pp. 37-71.

6. McCormick B.T., Hannon J.C., Hickslittle C.A., Newton M., Shultz B., Detling N., Young W.B. [The Relationship between Change of Direction Speed in the Frontal Plane, Power, Reactive Strength, and Strength]. International 
Journal of Exercise Science, 2014, iss. 7, no. 4, pp. 260-270.

7. Niculescu I.I. Motor, Somatic and Functional Assessment. Craiova, Universitaria Publ., 2006. $189 \mathrm{p}$.

8. Popović R., Aleksić A., Stojanović D., Stefanović M., Božić S., Popović M. [Evaluation of the Physical Fitness Level in Physical Education Female Students Using "Eurofit-Test"]. International Journal of Sports Science and Physical Education, 2017, iss. 6, no. 1, pp. 1-15.

9. Prieske O., Krüger T., Aehle M., Bauer E., Granacher U. [Effects of Resisted Sprint Training and Traditional Power Training on Sprint, Jump, and Balance Performance in Healthy Young Adults: A Randomized Controlled Trial]. Frontiers in Physiology, 2018, iss. 9, p. 156.

10. Rată G. The didactics of physical education and sport, Iasi, Pim Publ., 2008, pp. 113-118.

11. Rată G., Rată B.C. Abilities in motor activity. Bacău, Edusoft Publ., 2006, pp. 119-168.

12. Rodríguez C., Ospina J., Piedra J. [Athletic Body Stereotypes in the Academic Training of Students in the Physical Activity and Sport Sciences]. J. Hum. Sport Exerc., 2016, iss. 11, no. 1 , pp. $74-88$.

13. Sanjit M., Bidya R., Gopal C.S. [Comparative Study of Speed and Agility Between University Level Cricket and Football Player]. International Journal of Physiology, Nutrition and Physical Education, 2017, iss. 2, no. 1, pp. 386-388.
14. Schache A.G., Dorn T.W., Williams G.P., Brown N.A.T., Pandy M.G. [Lower-Limb Muscular Strategies for Increasing Running Speed]. J Orthop Sports Phys Ther., 2014, iss. 44, no. 10, pp. 813-824.

15. Simion G., Amzar L. The science of human movement research. Pitesti Universitatea Publ., 2009, pp. 221-236.

16. Sobolewski E., Thompson B., Conchola E., Ryan E. [Development and Examination of a Functional Reactive Agility Test for Older Adults]. Aging Clin Exp Res., 2018, iss. 30, no. 4, pp. 293-298.

17. Stan Z. Motor and Functional Assessment. Galati, Zigotto Publ., 2009, pp. 146-150.

18. Sumanta M., Samir H., Sujit S. [A Comparative Study of Selected Motor Fitness Component between Soccer Players and B.P. Ed Students]. IOSR Journal of Sports and Physical Education, 2016, iss. 3, no. 4, pp. 42-44.

19. Wagner M.C., Oden G.L., Glave A.P., William V. [Hyman,Development of agility utilising a multidimensional modality of plyometrics]. Journal of Fitness Research., 2014, iss. 3, no. 3, pp. 49-59.

20. Yarmak O., Blagii O., Palichuk Y., Hakman A., Balatska L., Moroz O., Galan Y. [Analysis of the Factor Structure of the Physical Condition of Girls 17-19 Year-Old]. Journal of Human Sport and Exercise, 2018, iss. 13, no. 2, pp. 259-268.

Received 20 September 2018

УдК 796.093.3

DOI: $10.14529 / \mathrm{hsm} 180414$

\title{
РАЗВИТИЕ ФОРМ ПРОЯВЛЕНИЙ БЫСТРОТЫ У СТУДЕНТОВ ПОСРЕДСТВОМ ЗАНЯТИЙ ФИЗИЧЕСКОЙ КУЛЬТУРОЙ
}

\author{
Л.Г. Талагир ${ }^{1}$, Дж.Д. Мокану1, Т.М. Икономеску1, В. Миндреску \\ ${ }^{1}$ Университет «Нижний Дунай», г. Галац, Румыния \\ ${ }^{2}$ Университет Трансильвании в Брашове, г. Брашов, Румыния
}

Цель. Разработать и оценить методику развития скорости как моторного навыка. Данная методика была применена в экспериментальной части исследования с учетом того, что все использованные методы могут быть объединены в форме метода повторения, состоящего из четырех связанных процедур. Материалы и методы. Экспериментальное исследование проводилось в 2016/2017 учебном году среди группы студентов-добровольцев, обучающихся в Университете «Нижний 


\section{Спортивная тренировка}

Дунай», Румыния. На развитие скорости как двигательного навыка и на последующую его оценку в рамках исследования выделялось 56 часов. Результаты. Применение тестов позволило нам оценить все важные формы проявления быстроты и их сочетания с другими двигательными навыками. Полученные результаты и статистические расчеты демонстрируют жизнеспособность и эффективность экспериментального расписания. Корреляционный анализ подчеркивает взаимосвязи, существующие между различными формами проявления быстроты, а также различия, зависящие от пола участников и индивидуальных характеристик каждой группы. Заключение. Результаты исследования позволяют нам объективно оценить проявление скоростных качеств у студентов. Тем не менее, они также указывают на тревожную тенденцию дефицита физической активности и анаэробной выносливости у учащихся. Физическая активность и анаэробная выносливость необходимы, чтобы справляться с интенсивными нагрузками, в которых проявляются скоростные качества. При этом улучшение непосредственно скоростных качеств - невероятно сложная задача.

Ключевые слова: занятия физической культурой в университете, время реакиии и скорость повторения, двигательные навыки, способность к ускорению, интенсивные усилия.

Талагир Лаурентиу-Габриэль, $\mathrm{PhD}$, Профессор, Факультет физического воспитания и спорта, Кафедра индивидуальных видов спорта и кинетотерапии, Университет «Нижний Дунай». Ул. Домняскэ, 47. 800008, г. Галац, Румыния. E-mail: gtalaghir@ugal.ro, ORCID: 0000-0002-3133-9192.

Мокану Джордж Данут, $\mathrm{PhD}$, Преподаватель, Факультет физического воспитания и спорта, Кафедра индивидуальных видов спорта и кинетотерапии, Университет «Нижний Дунай». Ул. Домняскэ, 47, 800008, г. Галац, Румыния. E-mail: gmocanu@ugal.ro, ORCID: 0000-0002-4763-4700.

Икономеску Теодора-Михаэла, $\mathrm{PhD}$, Доцент, Факультет физического воспитания и спорта, Кафедра спортивных игр и физического воспитания, Университет «Нижний Дунай». Ул. Домняскэ, 47, г. Галац, 800008, Румыния, E-mail: ticonomescu@ugal.ro, ORCID: 0000-0001-5780-4403.

Миндреску Вероника, $\mathrm{PhD}$, Старший преподаватель, Факультет физического воспитания и горных видов спорта, Университет Трансильвании в Брашове. Бульвар Эройлор, 29, г. Брашов, 500036, Румыния. E-mail: veronica_mindrescu@yahoo.com, ORCID: 0000-0003-0382-6206.

Поступила в редакцию 20 сентября 2018 г.

\section{ОБРАЗЕЦ ЦИТИРОВАНИЯ}

Development of Speed Manifestation Forms During Physical Education Classes at University / L.G. Talaghir, G.D. Mocanu, T.M. Iconomescu, V. Mîndrescu // Человек. Спорт. Медицина. - 2018. - Т. 18, № 4. - С. 95-102. DOI: $10.14529 / \mathrm{hsm} 180414$

\section{FOR CITATION}

Talaghir L.G., Mocanu G.D., Iconomescu T.M., Mîndrescu V. Development of Speed Manifestation Forms During Physical Education Classes at University. Human. Sport. Medicine, 2018, vol. 18, no. 4, pp. 95-102. DOI: $10.14529 / \mathrm{hsm} 180414$ 